\title{
Assessing the interaction effect of cost control systems and information technology integration on manufacturing plant financial performance
}

\author{
Adam S. Maiga a ${ }^{a}$, Anders Nilsson ${ }^{\text {b,*, }}$, Fred A. Jacobs ${ }^{\mathrm{c}}$ \\ ${ }^{a}$ School of Accounting, Florida International University, Miami, USA \\ ${ }^{\mathrm{b}}$ Department of Business Administration, Technology and Social Sciences, Accounting and Control, Luleå University of Technology, \\ Luleå, Sweden \\ ${ }^{\mathrm{c}}$ Department of Business, Economics and Law, Sundsvall, Sweden
}

\section{Keywords:}

IT integration

Cost control systems

Manufacturing plant financial performance

Activity-based costing

Volume-based costing

\begin{abstract}
A B S T R A C T
The interface between management control and information technology is an underdeveloped research area with a knowledge gap concerning its implications for financial performance. This study contributes to bridging this gap by investigating the interaction effect of cost control systems and information technology integration on manufacturing plant financial performance. We surveyed a sample of 518 managers of U.S. manufacturing plants, approximately evenly distributed between those using activity-based costing and volume-based costing. Using hierarchical regression analyses, results indicate that while information technology integration and cost control systems do not provide significant independent effects on plant financial performance, they do interact to positively impact manufacturing plant financial performance. Thus, our findings suggest that manufacturing plants will reap the greatest financial performance benefits from investments in activitybased cost control systems when combined with information technology integration.
\end{abstract}

(c) 2013 Elsevier Ltd. All rights reserved.

\section{Introduction}

Successful IT integration can deliver IT resources in support of the new roles and functions of workers as a result of redesigned and tightened business processes (Rockart, Ear, \& Ross, 1996). From a broad social and organizational point of view, a company with a high level of IT integration across different channels of operation may be able to transmit, combine, and process external data from customers and suppliers/vendors. It may also be effortless in such a company to share data among various internal systems (e.g., forecasting, production, shipment, and accounting) and to retrieve information from various databases for decision support (e.g., cost information, reporting tools). Further, external and internal systems can automatically reflect order changes in downstream processes or systems (e.g., inventory and manufacturing systems) (Barua, Konana, Whinston, \& Yin, 2004; Sikora \& Shaw, 1998) and help monitor order status at various stages in the process of a manufacturing plant (e.g., manufacturing, shipment).

The research on the organizational financial performance impact of information technology (IT) has been referred to as IT business value research (Kohli \& Grover, 2008; Melville, Kraemer, \& Gurbaxani, 2004; Mukhopadhyay, Kekre, \& Kalathur, 1995). Prior studies in this area suggest that organizations should realize greater financial performance benefits when such resources are increasingly integrated (Simoens \& Scott, 2005; Weiner, Savitz, Bernard, \& Pucci, 2004). However, the IT literature reveals mixed empirical results with respect to organizational financial performance achieved from IT integration (Bharadwaj, 2000; Chapman \& Kihn, 2009; Hunton, Lippincott, \& Reck, 2003; Poston \& Grabski, 2001). For example,

\footnotetext{
* Corresponding author.

E-mail addresses: maigaa@fiu.edu (A.S. Maiga), l.e.anders.nilsson@ltu.se (A. Nilsson), jacobsbae@gmail.com (F.A. Jacobs).
} 
Bharadwaj (2000) compared the financial performance of firms that had been recognized by InformationWeek magazine as IT leaders in their industry to the financial performance of a control group not having such recognition. She found that firms with high IT capabilities (firms in the study sample) outperformed firms from the control group. Hayes, Hunton, and Reck (2001) found that capital markets place value on enterprise resource planning (ERP) implementations, but Poston and Grabski (2001) found that ERP implementations have no effect on firm financial performance. Following these results, the research questions turn from whether investments in IT have a positive impact on financial performance to a question of when and why there is a financial performance effect (Dehning \& Richardson, 2002).

A parallel development in the literature has been to increasingly attend to contemporary management accounting developments, including "new" management accounting information such as activity-based costing (ABC) (e.g., AbdelMaksoud, Dugdale, \& Luther, 2005; Banker, Bardhan, \& Chen, 2008). Accounting systems require formalized categories for collecting and reporting information, and create a common language with which members of the organization can communicate (Wouters \& Verdaasdonk, 2002). This facilitates the coordination between different functions that need to provide input to the decision-making processes (Galbraith, 1973).

Despite many assertions of financial benefits resulting from ABC systems, the empirical results have been mixed (Bromwich \& Bhimani, 1989; Gordon \& Silvester, 1999; Innes \& Mitchell, 1995; Ittner, Lanen, \& Larcker, 2002; Rafiq \& Garg, 2002). For example, while empirical findings by Rafiq and Garg (2002) suggest that there is a strong relationship between ABC implementation and profitability, many other studies find no relationship between ABC and profitability (Bromwich \& Bhimani, 1989; Gordon \& Silvester, 1999; Innes \& Mitchell 1995; Ittner et al., 2002; Maiga \& Jacobs, 2008). Additionally, several reservations have been expressed regarding the efficacy of ABC (Innes, Mitchell, \& Sinclair, 2000; Malmi, 1997; Morrow \& Connolly, 1994)

There has been conjecture regarding why the effect of IT integration or cost control systems, such as ABC, has not been consistently shown to have a positive impact on organizational financial performance. Indeed, some studies claim that financial performance-enhancing programs have been implemented in ways that lack balance with competing priorities, thus resulting in a reduction of, or no increase in, financial performance (Shields, 1995). For example, Milgrom (1992) suggests that the value that a resource can bring to an organization might remain limited unless other complementary factors are adopted and implemented as well. This is in line with Milgrom and Roberts' (1995) framework which suggests that factors in a system of mutually enhancing elements will operate in such a way that doing more of any of these factors increases the attractiveness of doing more of the other factors in the system. These arguments suggest that successful outcomes of management accounting systems may be contingent upon the implementation of new manufacturing techniques.

While the literature does recognize the importance of contingency variables, there is little cross-fertilization between the stream of literature which highlights contemporary developments in cost control systems and the literature on organizationlevel IT integration (Drake \& Haka, 2008). Although the intense development of information technology over recent years opens new venues for modeling and integrating organizational activities (Berry, Coad, Harris, Otley, \& Stringer, 2009), and despite suggestions of potentially important synergies between IT and accounting, their complementarity effects on manufacturing plant financial performance have not been empirically assessed. As such, the interface of management control and information technology is still an under-developed area both empirically and theoretically (Granlund \& Mouritsen, 2003). This gap in accounting literature constitutes the motivation for this paper. Therefore, the first contribution of this study is to attempt to develop a workable framework that integrates existing theory and research in management accounting and information technology. The second contribution is to develop a theory-driven hypothesis and to attempt to bridge this gap between management accounting and IT by evaluating the possible interaction effect of cost control systems and IT integration on manufacturing plant financial performance. In so doing, we are responsive to Topkis (1995) who suggests that investments in information and production technologies cannot stimulate productivity and growth without a number of complementarity developments. To our knowledge no operationalizations of this complementarity have been presented so far, making this study interesting for continued research in this area. Based on these contributions, this study provides knowledge that adds to the research which seeks to integrate the information technology and management accounting literatures.

Using hierarchical regression analyses, our results indicate that while information technology integration and cost control systems do not provide significant independent effects on plant financial performance, they do interact to positively impact manufacturing plant financial performance. This finding implies that maximizing the performance benefits of cost control systems and information technology integration require attending to the integration between them, rather than treating the levels of cost control systems and information technology integration as independent decisions. The study thereby subscribes to, and provides statistically significant evidence in support of, the conclusion of Dechow, Richardson, and Sloan (2005: 691) who suggest that “...control cannot be studied apart from technology".

This paper is organized as follows. In the next section, the theoretical background and hypothesis development are presented. These topics are followed by the discussion of the research methods. Subsequent sections address the results, conclusions, and limitations of the study.

\section{Theoretical background and hypothesis development}

\subsection{Cost control systems}

ABC measures the cost and performance of activities, resources, and cost objects (Player \& Cobble 1999: 247), and evaluates whether those activities add value, thus providing a means of understanding how to most effectively reduce costs. ABC 
was promoted as a method for reducing inaccuracies experienced with traditional costing systems that arise from prevalent technology and competition (Dodd \& Lavelle, 2002). Proponents argue that ABC is a more refined cost system type that provides greater detail, better classifies costs according to behavior, reports cost information more frequently, can provide more accurate cost data, and results in the ability to calculate more variances (Pizzini, 2006). ABC may allow for "better" (i.e., more relevant and useful) data that enhance managerial decision-making, enabling improved performance (e.g., Cooper \& Kaplan, 1991a; Ittner et al., 2002; Johnson, 1992; Krumwiede, 1998).

Khanna (2002) argues that the primary failings of traditional costing systems are the inability to provide useful feedback or understand and allocate overhead costs. Traditional systems also have the potential inability to account for the size and diversity of products, as a larger or more complex item that may produce more revenue, may also consume a larger than presumed overhead cost (Doyle, 2002). Brewer, Brownlee, and Juras (2003) argue that these issues can have a negative effect on a company's financial performance.

Despite the fact that the ultimate aim of $A B C$ is promoted as the improvement of financial performance (Cooper \& Kaplan, 1991a), several reservations have been expressed regarding the efficacy of ABC (Innes et al., 2000; Malmi, 1997; Morrow \& Connolly, 1994). The arguments in support of ABC are based on the presumed comparative advantage that firms may derive from greater transparency and accuracy of information obtained from ABC (Banker et al., 2008; Cagwin \& Bouwman, 2002). However, Kaplan (1993) and others have caution that ABC implementation may not produce direct benefits. Indeed, the role of other facilitators and contextual factors, such as implementation of related organizational initiatives, has gained greater importance in this debate (Anderson, Hesford, \& Young, 2002; Banker et al., 2008; Chenhall, 2003; Henri, 2006).

\subsection{IT integration}

Prior research provides a well-agreed definition of information system integration, such as ERP, as "enterprise wide packages that tightly integrate business functions into a single system with a shared database" (Chapman \& Kihn, 2009; Lee \& Lee, 2000; Newell, Huang, Galliers, \& Pan, 2003; Quattrone \& Hopper, 2005). When integrated, the various information systems create an environment that provides a degree of interoperability which stand-alone "componentized" systems fail to achieve. In addition, integrated information technology not only enables process automation, but also can provide the ability to disseminate timely and accurate information, resulting in improved managerial and employee decision-making (Hitt, Wu, \& Zhou, 2002).

Although integrated information technology is generally designed and introduced by non-accountants, it is closely connected with the accounting processes (Chapman, 2005). Information technology plays a critical role in modern business, especially regarding the accounting function (Efendi, Mulig, \& Smith, 2006: 117), and management control (Dechow et al., 2005). IT has radically transformed the nature of business and accounting practice (Hunton, 2002). As indicated by Sadagopan (2003), some of the most ordinary accounting processes which are incorporated in an information technology system include: general ledger, accounts receivable, accounts payable, financial control, asset management, funds flow, cost centers, profit centers, profitability analysis, order and project accounting, product cost accounting, and performance analysis. Accordingly, information technology integration systems should have implications for all areas of accounting (Hunton, 2002; Sutton, 2006). The rationale for deployment of such systems generally is reductions in the routine tasks of management accountants (Arnold \& Sutton, 2007; Drury, 2008; Lowe, 2004) and the subsequent transition in their role from a transactionoriented information gatherer, to a business oriented information analyst (Granlund \& Lukka, 1998; Hunton, 2002), or more simply from the back office to the front office (Holtzman, 2004).

\subsubsection{Interaction effect of cost control systems and IT integration}

Information technologies, such as ERP systems, are packages of computer applications that support many, even most, aspects of a company's information needs (Davenport, 2000: 2). However, the idea that information systems are able to deliver support for management accounting is not new (Rom \& Rohde, 2007). IT represents a precious assistance in the search for and treatment of information needed in decision-making processes (O'Connor \& Martinsons, 2006). Thus, management accounting practices, whether traditional or modern, may become more efficient and effective when supported with integrated information technology (e.g., Baxendale \& Jama, 2003; Edwards, 2001; He, 2007; Lea, 2007; Lea \& Min, 2003; Scapens \& Jazayeri, 2003).

Integrated information technology, such as ERP systems, has been suggested to lead to the standardization of data collection formats and reporting, and to new opportunities for adapting accounting information to the needs that emerge in local decision situations (Granlund \& Malmi, 2002). IT can provide organizational members with quick and effective access to the right amounts of information (Hope \& Hope, 1997). If connectivity is enhanced through IT, firm members can more easily share individual interpretations of the cost information, thereby making consensus development more efficient.

Prior research (e.g., Cooper \& Kaplan 1991b; Estrin, Kantor, \& Albers, 1994; Pattison \& Arendt 1994) has identified specific environmental conditions that affect the potential benefits from the use of $A B C$. The prior research supports the proposition that under appropriate conditions more detailed costing information provided by $\mathrm{ABC}$ leads to improved decision-making, enabling improved performance. For example, Baxendale and Jama (2003) suggest that in an ABC environment, the availability and reliability of activity cost driver information becomes more beneficial when supported by integrated information technology. Furthermore, Kudyba and Vitaliano (2003) suggest that the enhanced flow of information brought about by IT integration and cost control systems throughout the company empowers decision makers to streamline operations by reducing unnecessary waste, such as idle factors of production (labor and capital), and increasing profitability. 


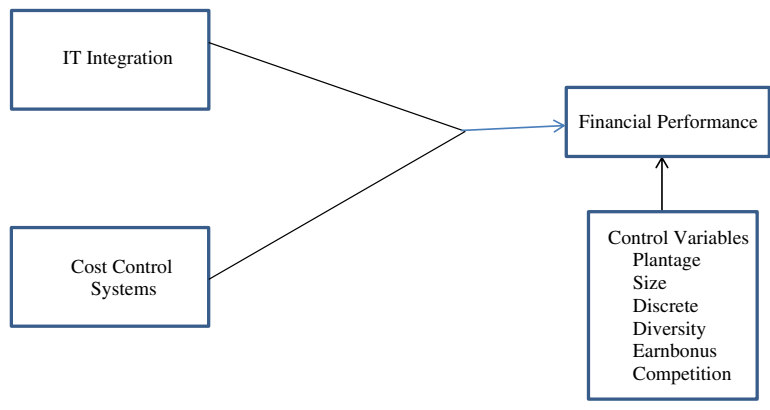

Fig. 1. Conceptual model.

Based on the above arguments, we contend that while a cost control system, such as $A B C$, provides the content and structure of data collection and reporting, and while an integrated information technology supplies the information processing and connectivity tools, it follows that neither cost control systems nor integrated information technology may have a direct significant impact on plant financial performance when used in isolation. Rather, cost control systems may interact with information technology integration to improve plant financial performance. This argument is in line with the contingency theory of management accounting which suggests that organizational performance requires fit between the use of management accounting systems and contextual variables (Baines \& Langfield-Smith, 2003; Chenhall, 2003; Chenhall \& Morris, 1986; Haldma \& Laats, 2002; Hoque, 2004; Hyvönen, 2007; Morton \& Hu, 2008; Otley, 1980). Thus, we hypothesize (Fig. 1):

H1: The two-way interaction between cost control systems and IT integration is positively related to manufacturing plant financial performance.

\section{Research design and methods}

\subsection{Sample}

The initial sample of 2506 U.S. manufacturing plants (both $A B C$ and non-ABC plants) used in this study was first used by Maiga and Jacobs (2008) in their study of the extent of ABC use and its consequences. To address the hypotheses, survey questionnaires were sent to the director of manufacturing, manager, and/or the chief operating officer of the manufacturing plant. The questionnaires ${ }^{1}$ were pre-coded to enable non-respondents to be identified for a second mailing and later pairing. A self-addressed, postage-paid envelope was attached for returning the completed questionnaire directly to one of the researchers.

The survey cover letter described the objectives of the study and promised anonymity. An explanation of the control number also appeared on the survey cover letter. Within the first three weeks, 478 plants responded. To increase the response rate, we sent follow-up letters and another copy of the questionnaire to those who had not responded. This second mailing resulted in 89 responding plants. The following criteria were used for inclusion of the responses in the data analysis: (1) each plant should be an investment center, (2) at least two complete responses should have been received from each plant, and (3) each manager should have held the current position for at least two years with the plant. A total of 20 plants was eliminated because they did not meet criterion 2 (questionnaires were received from only one respondent at the plant). Additionally, 29 responses were excluded for incompleteness. ${ }^{2}$ This process resulted in 518 usable responses ( 272 for the ABC group and 246 for the non-ABC group), a $20.67 \%$ response rate. Table 1 provides a more detailed analysis of the responses received.

Previous studies have indicated a varying $\mathrm{ABC}$ implementation rate in the range of some $20-30 \%$. For example Ittner et al. (2002) found a rate of $26 \%$, Maiga and Jacobs (2008) noted a rate of $27.6 \%$ and Banker et al. (2008) had a $19.8 \%$ implementation rate in their sample. After data collection, we could determine that our sample indicated a rather high ABC implementation rate of 52.5\%. Having used identical items and the same two-digit standard classification (SIC) as Banker et al. (2008) and Ittner et al. (2002) we decided to explore the reason for our implementation rate by means of a comparison with our sample and that of Banker et al. (2008) as the most recent of those studies. Results of this analysis, along with secondary data on U.S. manufacturers from Banker et al. (2008), are displayed in Table 2 below.

This comparison revealed that our sample was composed in such a way that each of the sectors food and kindred products, chemical and allied products, rubber and plastics products, and electronics and electrical equipment contributed more than $10 \%$ to the total sample. The implementation rate for each of these sectors turned out to be high, spanning from 44.8 to $82.7 \%$. This characteristic of our sample differentiates it from the sample in Banker et al. (2008) where these industries are represented to a much lower extent, and it also sets our sample apart from the percentage of U.S. manufacturers in the sectors concerned. If, as in this case, a large weight in the total sample is attributed to industry sectors with a high implementation

\footnotetext{
${ }^{1}$ The complete questionnaire is available from the corresponding author upon request.

${ }^{2}$ Because of contravening company policy, some preferred not to participate.
} 
Table 1

Summary of responses received.

\begin{tabular}{|c|c|c|c|}
\hline & $\mathrm{ABC}$ & Non-ABC (VBC) & Total \\
\hline First wave & 255 & 223 & 478 \\
\hline Second wave & 41 & 48 & 89 \\
\hline Total & 296 & 271 & 567 \\
\hline Plants eliminated from the study because they did not meet the required 2 or more response criteria & 11 & 9 & 20 \\
\hline Plants eliminated because of incomplete responses & 13 & 16 & 29 \\
\hline Plants with usable responses & 272 & 246 & 518 \\
\hline
\end{tabular}

rate this will also increase the implementation rate of the sample as a whole. The comparison also revealed differences between the studies in terms of which specific SIC codes, in the 20-40 interval, that had been used. There is thus a distinct possibility that our implementation rate has been affected by the sample composition.

Non-response bias is always a concern in survey research. We tested for non-response bias in two ways. First, we performed $t$-tests to determine if the sample was different from the general population of manufacturing plants used in this study. Data were obtained from the Annual Survey of Manufacturers conducted in the United States. This survey estimates a limited amount of industry-level data based on an annual survey. From this source, we were able to extract return on assets (ROA) and plant size as measured by the number of employees. We compared the $A B C$ responding sample and non- $A B C$ population that did not respond using the two measures. We also compared the total responding group (both $A B C$ and non- $A B C$ ) with the general population. In either case, neither ROA nor size was significantly different from the numbers provided by the Annual Survey of Manufacturers. Second, we tested for statistical differences in the responses between the early and late waves of survey respondents (early $A B C$ responds vs. late $A B C$ respondents; and total early respondents vs. total late respondents) with the last wave of surveys received considered representative of non-respondents (Armstrong \& Overton, 1977). $t$-tests were performed to compare the mean scores of the early and late responses. There were no statistically significant differences between the early and late respondents, providing some assurance concerning non-response bias.

Next, we calculated inter-respondent reliability using a Spearman-Brown interclass correlation coefficient (Shrout \& Fleiss, 1979). The results indicated that inter-respondent reliability was high across all questions in the survey (ranging from 0.76 to 0.83). Therefore, we averaged the responses from each plant to arrive at a single representation of each variable value per plant.

\subsection{Measurement and validation of variables}

The variables used to test the hypotheses are cost control system, IT integration, financial performance, and the following control variables: Plant Age, Size, Discrete, Diversity, Competition, and Earnbonus. The Appendix contains an abbreviated copy of the research questionnaire used to measure the self-reported variables.

\subsubsection{Cost control systems}

We followed Banker et al. (2008) for inquiry designed to identify $A B C$ and non- $A B C$ [volume-based costing (VBC)] adopting plants. The $A B C$ adoption variable was defined based on the response to the survey question asking whether $A B C$ was implemented at the plant $(0=$ not implemented, $1=$ plan to implement, $2=$ extensively implemented $)$. For the purpose of our study, we collapsed the first two categories into one category, which represents plants that had not implemented $A B C$ at the time of the survey. As in prior studies (e.g., Anderson, 1995; Gosselin, 1997; Ittner et al., 2002; Krumwiede, 1998), we focused on extensive use of $A B C$ data rather than a continuum of $A B C$ adoption levels to avoid problems with plants that are just beginning to implement $A B C$ or that have not achieved full commitment to the systems. Hence, we measure $A B C$ as a $0-1$ dummy variable where zero represents "no implementation" and one represents "extensive implementation".

\subsubsection{IT integration}

For the purpose of this study, we measured this variable based on prior studies (e.g., Barua et al., 2004; Chapman \& Kihn, 2009). The construct was measured on a seven-point Likert scale ( $1=$ never, $7=$ all the time) with the following inquiries: ( 1$)$ "Our plant's information systems allow continuous monitoring of order status at various stages in the process (e.g., manufacturing, shipping)." (2) "Data can be shared easily among various internal systems (e.g., forecasting, production, manufacturing, shipment, finance, accounting, etc.)." (3) "Order changes are automatically reflected in downstream processes or systems (e.g., inventory, manufacturing resource planning, and manufacturing systems)." (4) "Employees are able to retrieve information from various databases for decision support (e.g., cost information, reporting tools)." (5) "Our systems can easily transmit, integrate, and process data from suppliers and customers." We used a seven-point Likert scale to increase the sensitivity of the measurement instrument. ${ }^{3}$ Factor analysis of the scale produced one component with an eigenvalue of $79.371 \%$ of the total variation. A reliability check of the instrument for the study produced a Cronbach (1951) alpha of 0.883 . Thus, the IT integration score was calculated as the average of the manager's score for the five items in the instrument.

\footnotetext{
${ }^{3}$ The use of a seven-point scale is believed to be appropriate as it is the most common scale in U.S. research (Wolak, Kalafatis, \& Harris, 1998).
} 
Table 2

Excerpt from sample distribution by industry in comparison to Banker et al. (2008).

\begin{tabular}{|c|c|c|c|c|c|}
\hline Industry sector & $\begin{array}{l}\text { SIC } \\
\text { code }\end{array}$ & $\begin{array}{l}\text { Percent of sample } \\
\text { (Banker et al., 2008) }\end{array}$ & $\begin{array}{l}\text { Percent of U.S. } \\
\text { manufacturers }\end{array}$ & $\begin{array}{l}\text { Percent of sample } \\
\text { in present study }\end{array}$ & $\begin{array}{l}\text { Implementation rate } \\
\text { in present study }\end{array}$ \\
\hline Food and kindred products & 20 & $3.76 \%$ & $5.76 \%$ & $10.425 \%$ & $57.4 \%$ \\
\hline Chemicals and allied products & 28 & 6.88 & 3.41 & 11.197 & 44.8 \\
\hline Rubber and plastics & 30 & 5.92 & 0.52 & 10.618 & 58.2 \\
\hline $\begin{array}{l}\text { Electronics and electrical } \\
\text { equipment }\end{array}$ & 36 & 13.44 & 4.71 & 10.039 & 82.7 \\
\hline
\end{tabular}

\subsubsection{Financial performance}

Based on prior studies (Kinney \& Wempe 2002; Maiga \& Jacobs 2008), we measured financial performance by asking respondents to indicate the extent to which their plants have experienced improvement in (1) "Return on sales (net income before corporate expenses divided by sales)", (2) "Turnover on assets (sales divided by total assets)", and (3) "Return on assets (net income before corporate taxes divided by total assets)". The construct was measured on a seven-point Likert scale ( 1 = much worse than our competitors, $7=$ much better than our competitors).

Factor analysis of the scale produced one component with an eigenvalue of $80.710 \%$ of the total variation. A reliability check of the instrument for the study produced a Cronbach (1951) alpha of 0.854. Thus, the financial performance was measured as the average response of the manager's score for the three items in the instrument.

\subsubsection{Control variables}

Some of the cross-sectional variations in plant profitability can be explained only if controls are appropriately applied. Hence, we controlled for the impact of plant characteristics on manufacturing performance following prior studies (Banker et al., 2008; Bjørnenak, 1997; Brown, Booth, \& Giacobbe, 2004; Ittner et al., 2002; Maiga \& Jacobs, 2008). We included the following control variables in our tests:

Plant age (PLANTAGE) is likely to play a significant role since older plants often fail to realize the impact of technologyenabled processes on manufacturing performance (Banker et al., 2008). Plant age represented the number of years since plant start-up to the time of the study (Banker et al., 2008).

Plant size (SIZE) is likely to impact manufacturing performance since smaller plants are likely to be more agile in responding to customer needs compared to larger plants, ceteris paribus (Banker et al., 2008; Hendricks \& Singhal, 1997). Plant size was measured as the number of plant employees (Banker et al., 2008).

Discrete product environment (DISCRETE) indicated operations where the primary products were measured in numeric quantities, while process manufacturing indicated whether the primary products were measured by weight or volume. A discrete production environment was expected to lead to higher manufacturing performance (Bardhan, Whitaker, \& Mithas, 2006; Ittner et al., 2002). DISCRETE = 1 if the nature of manufacturing operations for primary products was discrete, 0 otherwise (Banker et al., 2008).

Product diversity (DIVERSITY) occurs when plants offer a varied set of products - possibly at a higher price-to sell more goods and to further segment the market. As a result there is a trade-off between efficiency, cost or time reduction, and diversity (Lancaster, 1979). The accounting and operations management literatures have emphasized the potential costs from increasing variety (e.g., Cooper \& Kaplan, 1991a; Hayes \& Wheelwright, 1984; Miller \& Vollman, 1985; Skinner, 1974). Similarly we expected that product diversity would negatively impact manufacturing performance. DIVERSITY was measured as 1 if products were diverse, 0 otherwise.

Earnings-based bonus (EARNBONUS) is a variable included to control for the possibility that earnings-based bonus plans for management result in the achievement of higher manufacturing performance. That is, it is possible that plants that provide earnings-based bonus plans are more likely to improve their performance (Banker, Potter, \& Srinivasan, 2000; Bruns \& McKinnon, 1993; Coates, Davis, Emmanuel, Longden, \& Stacey, 1992). Earnbonus equaled 1 if the plant had an earnings-based bonus plan, 0 otherwise (Kinney \& Wempe, 2002; Maiga \& Jacobs, 2008).

Market competition (COMPETITION), according to economic theory, enhances incentives for raising performance. Evidence of the positive role of market competition is given in studies by Dutz and Hayri (1999) and Nickell (1996). However, La Porta and Lopenz-de-Silanes (1999) failed to find performance improvement with more intense competition. Market competition was measured on a seven-point Likert scale ( $1=$ low competition, $4=$ medium competition, $7=$ high competition $)$ by asking respondents to indicate "the extent to which their plants have experienced market competition over the last five years".

\subsection{Data analysis techniques}

In empirical contingency research, hierarchical regression analysis is used to establish the existence of a statistically significant interaction effect (e.g., Arnold \& Evans, 1979; Cohen \& Cohen, 1983; Cronbach, 1987; Southwood, 1978). In addition to running a regression with only the control variables [cf. Equation (1)], we ran two regressions, one with the control variables and the main effects [cf. Equation (2)] and another with the control variables, the main effects, and the interaction term 
Table 3

Respondents' characteristics.

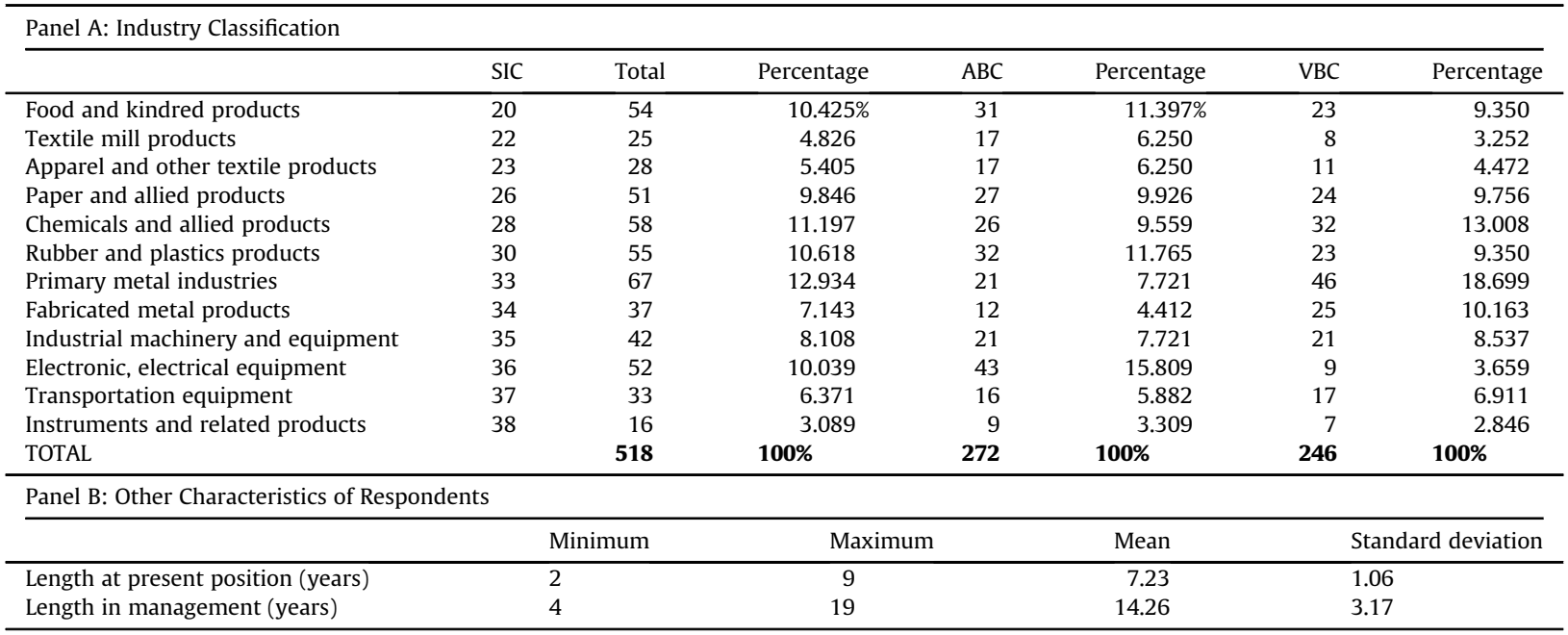

[cf. Equation (3)]. A significant interaction effect is confirmed by the statistical significance of the additional variance explained by the inclusion of the interaction term (i.e., the significance of the increase in $R^{2}$ ). This method is equivalent to the simpler and more direct assessment of the significance of the $t$-value associated with the coefficient of the product term (see Arnold, 1982: 157; Jaccard, Turrisi, \& Wan, 1990: 22; Southwood, 1978: 1168). Since the main effects of the two-way interaction model are arbitrary and have no theoretical meaning as we have used non-ratio scales (Allison, 1977; Schoonhoven, 1981; Southwood, 1978) the hierarchical approach also permits the main effects and the interactive effects of the independent variables to be analyzed separately. Following these approaches, the following regression models were employed:

$$
\begin{aligned}
\mathrm{F}-\text { Performance }= & \alpha_{0}+\alpha_{1} \text { Plantage }+\alpha_{2} \text { Size }+\alpha_{3} \text { Discrete }+\alpha_{4} \text { Diversity }+\alpha_{5} \text { Earnbonus }+\alpha_{6} \text { Competition }+\zeta \\
\text { F- Performance }= & \gamma_{0}+\gamma_{1} \text { Plantage }+\gamma_{2} \text { Size }+\gamma_{3} \text { Discrete }+\gamma_{4} \text { Diversity }+\gamma_{5} \text { Earnbonus }+\gamma_{6} \text { Competition }+\gamma_{7} \text { ITI } \\
& +\gamma_{8} \text { CCS }+\varepsilon \\
\text { F- Performance }= & \beta_{0}+\beta_{1} \text { Plantage }+\beta_{2} \text { Size }+\beta_{3} \text { Discrete }+\beta_{4} \text { Diversity }+\beta_{5} \text { Earnbonus }+\beta_{6} \text { Competition }+\beta_{7} \text { ITI } \\
& +\beta_{8} \mathrm{CCS}+\beta_{9}(\mathrm{ITI} \times \mathrm{CCS})+\delta
\end{aligned}
$$

where F-Performance = manufacturing plant financial performance as measured by the average of three response items, i.e., return on sales (ROS), turnover on assets (TOA), and return on assets (ROA). Plantage $=$ plant age, Size $=$ plant size, Discrete $=$ discrete production environment, Diversity = product diversity, Earnbonus = earnings-based bonus, and Competition = market competition. CCS $=$ cost control systems operationalized as a dummy variable with $0=$ volume-based costing and $1=$ activity-based costing. ITI $=$ information technology integration. ITI $\times$ CCS $=$ interaction term. $\zeta, \varepsilon$ and $\delta$ are the error terms.

We make three assumptions when interpreting the estimation results of the models. First, we assume that some firms have not chosen their IT integration and cost control systems optimally, so that manufacturing plant financial performance will vary cross-sectionally with the observed IT integration and cost control system choices. Second, we assume that our variables have low measurement error and the functional form of the models is appropriate. Finally, we assume IT integration, cost control systems, and the control variables are exogenous, making the coefficient estimates for our models consistent.

\section{Results}

In this section, we first present the descriptive statistics. Then we examine the hypotheses and conduct further analyses.

\subsection{Descriptive statistics}

The descriptive statistics in Table 3, Panel A, provide the profile of the responding companies, showing that they constitute a broad spectrum of manufacturers as defined by the two-digit SIC code. The sample composition has representation in primary metals (12.934\%), followed by chemicals and allied products (11.197\%), rubber and plastics (10.618\%), food and kindred products (10.425\%), and electronic, electrical equipment (10.039\%). Additional information on respondents' characteristics is provided in Table 3, Panel B. Answers to the question regarding number of years with the manufacturing plant showed that the respondents have a mean of 7.23 years in their current position. To the number of years in management 
Table 4

Correlations, means and standard deviations for the variables $(N=518)$.

\begin{tabular}{|c|c|c|c|c|c|c|c|c|c|c|}
\hline & & 1. & 2. & 3. & 4. & 5. & 6. & 7. & 8. & 9. \\
\hline 1. & Plantage & 1 & & & & & & & & \\
\hline 2. & Size & -0.014 & 1 & & & & & & & \\
\hline 3. & Discrete & $0.792 * *$ & 0.008 & 1 & & & & & & \\
\hline 4. & Diversity & 0.020 & $0.476^{* *}$ & 0.011 & 1 & & & & & \\
\hline 5. & Earnbonus & $0.780^{* *}$ & -0.013 & $0.861^{* *}$ & -0.002 & 1 & & & & \\
\hline 6. & Competition & $0.020 * *$ & $0.500 * *$ & 0.017 & $0.735^{*}$ & -0.017 & 1 & & & \\
\hline 7. & CCS & $0.095^{*}$ & 0.031 & $0.094 *$ & 0.018 & 0.075 & 0.025 & 1 & & \\
\hline 8. & ITI & $0.093 * *$ & $0.101^{*}$ & $0.114^{* *}$ & 0.083 & 0.071 & $0.133^{*} *$ & $0.159 * *$ & 1 & \\
\hline 9. & F-Performance & 0.011 & $0.231^{* *}$ & -0.028 & $0.485^{* *}$ & -0.011 & $0.455^{* *}$ & 0.061 & 0.0271 & \\
\hline \multicolumn{2}{|c|}{ Mean } & 3.392 & 3.284 & 0.419 & 0.367 & 0.417 & 4.176 & 0.525 & 4.214 & 4.091 \\
\hline \multicolumn{2}{|c|}{ Std. Dev. } & 0.504 & 0.716 & 0.494 & 0.482 & 0.494 & 1.590 & 0.500 & 1.399 & 1.610 \\
\hline
\end{tabular}

*Significant at 0.05 level (two-tailed), **significant at the 0.01 level (two-tailed).

Note: Plantage $=$ plant age, Discrete $=$ discrete production environment, Diversity $=$ product diversity, Earnbonus $=$ earning-based bonus, Competition $=$ market competition, $\mathrm{CCS}=$ cost control systems, ITI $=$ information technology integration, F-Performance $=$ financial performance.

question, respondents indicated a mean of 14.26 years. It appears from their positions and tenure that the respondents are knowledgeable and experienced, have access to information upon which to provide reliable perceptions, and are otherwise well qualified to provide the information required. ${ }^{4}$

The Pearson correlation matrix as well as means and standard deviations for the variables included in the model is shown in Table 4. It is notable that the lack of significant correlation between product diversity and cost control systems can be considered surprising, given that product diversity is often presented as a motive for implementing sophisticated costing systems (e.g., Cooper, 1988; Estrin et al., 1994). However, a case study by Abernethy, Lillis, Brownell, and Carter (2001) on the implications of product diversity of cost systems design in Australia indicated that the design of cost systems was not influenced by product diversity. Also, using a sample of UK companies at business unit level, Al-Omiri and Drury (2007) found no association between the level of cost system sophistication and cost structure and product diversity. Similarly, Bjørnenak (1997) and Krumwiede (1998) failed to link cost systems with product diversity.

\subsection{Regression results}

Before presenting the regression results, we first discuss the issue of multicollinearity. Dewar and Werbel (1979) argued that hierarchical models like Equation (2) suffer from multicollinearity since the cross-product term is likely to be strongly correlated with the terms that compose it. However, several researchers (Gupta \& Govindarajan, 1993; Smith \& Sasaki, 1979; Southwood, 1978) have demonstrated that such multicollinearity can be completely eliminated by manipulating the origin points for the continuous variables. Therefore, in this study, the continuous variable (IT integration) is mean centered before entering to avoid nonessential multicollinearity. Such a transformation in the origin points does not in any way affect the value or the significance of the regression coefficients. Hence, two statistical measures of multicollinearity are the tolerance (TOL) value and the variance inflation factor (VIF) (Hair, Anderson, Tatham, \& Black, 1998). A low tolerance value indicates a high degree of collinearity. The VIF and TOL measures assume normality and are typically relative measure. A high tolerance value (above 0.10) and low VIF value (below 10) usually suggest a relatively small degree of multicollinearity (Hair et al., 1998). In the regression in Table 5, the largest variance inflation factor was 4.585 and the lowest tolerance value 0.218 , suggesting no bias in the standard errors of regression coefficients among the variables used in the models.

The standardized regression results are reported in Table 4. Equation (1) shows the results for the control variables. Neither Plantage nor Size has a significant impact on plant financial performance $(\alpha=0.027, p=0.647 ; \alpha=-0.053, p=0.190$, respectively), the coefficient for Discrete is significant, but negative ( $\alpha=-0.249, p=0.001$ ). However, Diversity, Earnbonus, and Competition have significant effect on financial performance [Diversity $(\alpha=0.291, p=0.000)$, Earnbonus $(\alpha=0.201$, $p=0.005)$, and Competition $(\alpha=0.405, p=0.000)$ ].

In Equation (2), results indicate the main effects of cost control systems and IT integration. Neither variable is significantly related to financial performance ( $\gamma=0.051, p=0.145$, and $\gamma=-0.014, p=0.691$, respectively). However, as shown in Equation (3), interacting variables (cost control systems $\times$ information technology integration) significantly associated with financial performance $(\beta=0.237, p=0.000)$. In addition, the explained variance $\left(R^{2}\right)$ was $42.5 \%$, hence increasing $2.6 \%$ from the main effects model (Equation (2)), with significant $F$-value $(41.749, p=0.000) .{ }^{5}$ Therefore, $\mathrm{H} 1$ was supported. The results indicate that while information technology integration and cost control systems do not provide significant independent effects on plant financial performance, they do interact to positively impact manufacturing plant financial performance. ${ }^{6}$

\footnotetext{
4 The range of $\mathrm{ABC}$ adoption length varies from 5 to 19 years.

${ }^{5}$ For a two-way interaction equation (i.e., Equation (3)), all main effects should be included, and it should be noted that the coefficients obtained for these main effects are not directly interpretable (Cohen \& Cohen 1983: 348; Govindarajan \& Fisher, 1990). Therefore, the focus is on the two-way interaction coefficient.

${ }^{6}$ We also regressed each financial performance measure (ROS, TOA, ROA) on the independent variables. Results indicate that, similar to the results in Table 4 , the coefficient of the interaction term (CCS $\times$ ITI) is significant and positive for each dependent variable (ROS, TOA, ROA).
} 
Table 5

Results of regression for financial performance.

\begin{tabular}{|c|c|c|c|c|c|c|}
\hline & \multicolumn{2}{|c|}{ Equation (1) } & \multicolumn{2}{|c|}{ Equation (2) } & \multicolumn{2}{|c|}{ Equation (3) } \\
\hline & $\alpha$ & $p$-value & $\beta$ & $p$-value & $\beta$ & $p$-value \\
\hline Plantage & 0.027 & 0.647 & 0.024 & 0.683 & 0.023 & 0.698 \\
\hline Size & -0.053 & 0.19 & -0.054 & 0.185 & -0.075 & 0.06 \\
\hline Discrete & -0.249 & 0.001 & -0.25 & 0.001 & -0.227 & 0.002 \\
\hline Diversity & 0.291 & 0 & 0.29 & 0 & 0.302 & 0 \\
\hline Earnbonus & 0.201 & 0.005 & 0.202 & 0.005 & 0.198 & 0.005 \\
\hline Competitive & 0.405 & 0 & 0.407 & 0 & 0.427 & 0 \\
\hline CCS & & & 0.051 & 0.145 & 0.052 & 0.131 \\
\hline ITI & & & -0.014 & 0.691 & -0.188 & 0 \\
\hline $\mathrm{CCS} \times \mathrm{ITI}$ & & & & & 0.237 & 0 \\
\hline$R^{2}$ & & 0.396 & & 0.399 & & 0.425 \\
\hline Adj. $R^{2}$ & & 0.389 & & 0.39 & & 0.425 \\
\hline$\Delta R^{2}$ & & - & & 0.003 & & 0.026 \\
\hline$F(p$-value $)$ & & $55.948(0.000)$ & & $42.246(0.000)$ & & $41.749(0.000)$ \\
\hline
\end{tabular}

Note: Plantage $=$ plant age, Discrete $=$ discrete production environment, Diversity $=$ product diversity, Earnbonus $=$ earning-based bonus, Competition = market competition, CCS $=$ cost control systems, ITI = information technology integration.

\section{Discussion, conclusions, limitations and subsequent research}

This study assesses the interaction effect of cost control systems and IT integration on manufacturing plant financial performance. The results of the study support the theoretical arguments. While the main effects of IT integration and cost control systems on plant financial performance are not significant, their interaction effect indicates a significant positive effect on plant financial performance. As suggested by Ashby's (1958) law of requisite variety, the greater variety in cost information resulting from cost control system practices may require a matching level of variety in information flows, enabled by a high level of IT integration.

On the basis of the findings of this survey, the results of this study show that the cost control system/IT integration interface provides a plausible explanation of conflicting results in prior studies assessing the relationship between $A B C$ or information technology on financial performance in isolation. The results are consistent with theoretical arguments presented in the information systems literature (e.g., Sambamurthy, Bharadwaj, \& Grover, 2003), and extend past findings in information systems integration (Bharadwaj, 2000). This study also extends past management accounting research that advocates systemic approaches to examining the effectiveness of management accounting systems (e.g., Chenhall, 2003; Chenhall \& Langfield-Smith, 1998), and its results help extend the boundaries of cost control systems.

The findings of this study have both theoretical and practical implications. A theoretical implication of the results is the necessity of addressing performance effects of cost control systems jointly with information technology. The focus on the interaction effect of cost control systems and IT integration on manufacturing plant financial performance represents an interesting and relatively unexplored area in management accounting research. At the level of practice, the findings provide practical guidance to managers involved in resource allocation decisions. This study's findings recommend that in terms of cost control systems, such as ABC, IT integration should be adopted as it is interacts with cost control systems to significantly impact manufacturing plant financial performance.

Limitations of this study should be mentioned. First, $A B C$ implementation was measured as a $0-1$ variable in our study. It is possible that using a more granular scale to measure the extent of $A B C$ implementation, including the level of $A B C$ integration and the time lag since $A B C$ implementation (Banker et al., 2008). For example, it is possible to identify empirically the appropriate definition(s) for the adoption and non-adoption of $A B C$ by testing the homogeneity of various definitions of $A B C$ adoption and non-adoption across the level of competition, product customization, manufacturing overhead cost percentage and size of operating units (Brierley, 2011). This may provide greater insights on the interaction effect of cost control systems and information technology integration on plant financial performance.

Second, the scales employed in this study represent individuals' perceptions of the variables used and, consequently, they may not reflect objective reality. Future studies can extend this study by utilizing different methodologies, such as case studies, and adopting a longitudinal approach, which would strengthen the underlying theory suggested by this study. Third, this study examines manufacturing performance strictly in financial terms. Other dimensions of performance, including quality, flexibility, and manufacturing cycle time and lead time, should be taken into consideration in future studies (see, for example, Ittner et al., 2002). Fourth, as the sample was derived from U.S. manufacturing plants, the results of this study can only be generalized to this sector of the economy. Opportunities exist to extend this study to other industries and other countries. Also, further research is necessary to validate the present results.

Despite the limitations above, this study provides additional evidence regarding the complex issue of IT and $A B C$ and performance. 


\section{Appendix}

\section{Survey questions}

Please answer the questionnaire (or pass it to the most appropriate person within the plant and return it to the address mentioned in the cover letter. We recognize that some of the information in this survey may be sensitive, but we assure you that the data will only be used in the aggregate in the study, and the answers in this questionnaire will be treated in the strictest confidence and no information gained from this survey will be identified with any particular person or manufacturing plant.

\section{PART I}

1. IT Integration

Never

All the

(a) Our plant's information systems allow continuous monitoring of order status at various stages in the process (e.g. manufacturing, shipping)

(b) Data can be shared easily among various internal systems (e.g. forecasting, production, manufacturing, shipment, finance, accounting, etc.)

(c) Order changes are automatically reflected in downstream processes or systems (e.g. inventory, manufacturing resource planning, and manufacturing systems.) $\quad \begin{array}{llllllll}1 & 2 & 3 & 4 & 5 & 6 & 7\end{array}$

(d) Employees are able to retrieve information from various databases for decision support (e.g. cost information, reporting tools.) $\begin{array}{lllllll}1 & 2 & 3 & 4 & 5 & 6 & 7\end{array}$

(e) Our systems can easily transmit, integrate, and process data from suppliers and customers. $\begin{array}{lllllll}1 & 2 & 3 & 4 & 5 & 6\end{array}$

2. ACTIVITY-BASED COSTING (ABC) - Please indicate the status of implementation of activity-based costing systems in your plant.

$0=$ No implementation

$1=$ Plan to implement

$2=$ Extensive implementation

If you have ticked " 2 " on question 2 above, please indicate the length of ABC adoption:

1 to 4 years

5 to 9 years

10 to 14 years

15 to 19 years

Over 20 years

3. PLANTAGE - How many years has it been since plant start-up?

$$
\begin{aligned}
& 1=\text { Less than } 5 \text { years; } \\
& 2=5-10 \text { years; } \\
& 3=11-20 \text { years; } \\
& 4=>20 \text { years }
\end{aligned}
$$


4. SIZE - How many employees are at this plant location?

$1=$ Less than 100 ;

$2=100-249$;

$3=250-499$;

$4=500-999$;

$5=>1000$ employees

5. DISCRETE - What is the nature of manufacturing operations for primary products at this plant?

$1=$ Discrete

$0=$ Otherwise (hybrid or process)

6. DIVERSITY - Please indicate whether your products are

$0=$ not diverse

$1=$ diverse

7. COMPETITION - Please indicate the extent to which your plant has experienced market competition over the last five years:

Low

competition

1
Medium

competition

3
4

5
High

competition

8. EARNBONUS - Plant managers are compensated through earnings-based bonus plans

$$
\begin{aligned}
& 0=\text { no } \\
& 1=\text { yes }
\end{aligned}
$$

\section{PROFITABILITY}

Please indicate the extent to which your plant has experienced improvement in profitability over the last five years compared to your major competitors.

$$
\begin{aligned}
& \text { Much worse } \\
& \text { than our major } \\
& \text { competitors }
\end{aligned}
$$

Much better than our major competitors

a. Return on sales (net income before corporate expenses divided by sales)

b. Turnover on assets (sales divided by total assets)

c. Return on assets (net income before corporate taxes divided by total assets)

2

3

3

45

1

2

Please answer the following:

11. Number of years at this position?

12. Number of years in management?

13. What is your industry two-digit SIC code? 


\section{References}

Abdel-Maksoud, A., Dugdale, D., \& Luther, R. (2005). Non-financial performance measurement in manufacturing companies. The British Accounting Review, 37, 261-297.

Abernethy, M. A., Lillis, A. M., Brownell, P., \& Carter, P. (2001). Product diversity and costing system design choice: field study evidence. Management Accounting Research, 12(3), 261-279.

Al-Omiri, M., \& Drury, C. (2007). A survey of factors influencing the choice of product costing systems in UK organizations. Management Accounting Research, $18,399-424$.

Allison, P. D. (1977). Testing for interaction in multiple regression. American Journal of Sociology, 83, $144-153$.

Anderson, S. W. (1995). A framework for assessing cost management system changes: the case of activity-based costing implementation at General Motors, 1986-1993. Journal of Management Accounting Research, 7, 1-51.

Anderson, S. W., Hesford, J., \& Young, S. M. (2002). Factors influencing the performance of activity-based costing teams: a field study of ABC model development time in the automobile industry. Accounting, Organizations and Society, 27, 195-211.

Armstrong, J. S., \& Overton, T. (1977). Estimating non-response bias in mail surveys. Journal of Marketing Research, 14, $396-402$.

Arnold, H. J. (1982). Moderator variables: a clarification of conceptual, analytic and psychometric issues. Organizational Behavior and Human Performance, 29, $143-174$.

Arnold, H. J., \& Evans, M. G. (1979). Testing multiplicative models does not require ratio scales. Organizational Behavior and Human Performance, 24, 41-59.

Arnold, V., \& Sutton, S. G. (2007). The impact of enterprise systems on business and audit practice and the implications for university accounting education. International Journal of Enterprise Information Systems, 3(4), 1-21.

Ashby, W. R. (1958). Requisite variety and its implications for the control of complex systems. Cybernetica, 1(2), 83-99.

Baines, A., \& Langfield-Smith, K. (2003). Antecedents to management accounting change: a structural equation approach. Accounting, Organizations and Society, 28(7,8), 675-698.

Banker, R. D., Bardhan, I. R., \& Chen, T. Y. (2008). The role of manufacturing practices in mediating the impact of activity-based costing on plant performance. Accounting, Organizations and Society, 33, 1-19.

Banker, R. D., Potter, G., \& Srinivasan, D. (2000). An empirical investigation of an incentive plan that includes non-financial performance measures. The Accounting Review, 75(1), 65-92.

Bardhan, I. R., Whitaker, J., \& Mithas, S. (2006). Information technology, production process outsourcing and manufacturing plant performance. Journal of Management Information Systems, 23(2), 13-40.

Barua, A., Konana, P., Whinston, A. B., \& Yin, F. (2004). Assessing Internet enabled business value: an exploratory investigation. MIS Quarterly, 28(4), $585-620$.

Baxendale, S. J., \& Jama, F. (2003). What ERP can offer ABC. Strategic Finance, 85(2), 54-57.

Berry, A. J., Coad, A. F., Harris, E. P., Otley, D. T., \& Stringer, C. (2009). Emerging themes in management control: a review of recent literature. The British Accounting Review, 41, 2-20.

Bharadwaj, A. S. (2000). Resource-based perspective on information technology capability and firm performance: an empirical investigation. MIS Quarterly, 24(1), 169-196.

Bjørnenak, T. (1997). Diffusion and accounting: the case of ABC in Norway. Management Accounting Research, 8(1), 3-17.

Brewer, P., Brownlee, R., II, \& Juras, P. (2003). Global Electronics, Inc.: ABC implementation and the change management process. Issues in Accounting Education, 18(1), 49-69.

Brierley, J. A. (2011). Why the proper definition of the ABC matters: a note. Advances in Management Accounting, 19, 225-249.

Bromwich, M., \& Bhimani, A. (1989). Management accounting: Evolution, not revolution. London: Chartered Institute of Management Accountants,

Brown, D. A., Booth, P., \& Giacobbe, F. (2004). Technological and organizational influences on the adoption of activity-based costing in Australia. Accounting and Finance, 44, 329-356.

Bruns, W. J., Jr., \& McKinnon, S. M. (1993). Information and managers: a field study. Journal of Management Accounting Research, 5(84), 35-46.

Cagwin, D., \& Bouwman, M. J. (2002). The association between activity-based costing and improvement in financial performance. Management Accounting Research, 13, 1-39.

Chapman, C. S. (2005). Not because they are new: developing the contribution of enterprise resource planning systems to management control research. Accounting, Organizations and Society, 30, 685-689.

Chapman, C. S., \& Kihn, L. A. (2009). Information systems integration, enabling control and performance. Accounting Organizations and Society, $34,151-169$.

Chenhall, R. (2003). Management control systems design within its organizational context: findings from contingency-based research and directions for the future. Accounting, Organizations and Society, 28, 127-168.

Chenhall, R. H., \& Langfield-Smith, K. (1998). Adoption and benefits of management accounting practices: an Australian study. Management Accounting Research, 9, 1-19.

Chenhall, R., \& Morris, D. (1986). The impact of structure, environment and interdependencies on the perceived usefulness of management accounting systems. The Accounting Review, 61, 16-35.

Coates, J. B., Davis, E. W., Emmanuel, C. R., Longden, S. G., \& Stacey, R. J. (1992). Multinational companies performance measurement systems: international perspectives. Management Accounting Research, 3, 133-150.

Cohen, J., \& Cohen, P. (1983). Applied multiple regression/correlation analysis for the behavioral sciences. Hillsdale: Erlbaum.

Cooper, R. (1988). The rise of activity-based costing-part three: how many cost drivers do you need, and how do you select them? Journal of Cost Management34-46. Manufacturing Industry.

Cooper, R., \& Kaplan, R. S. (1991a). Profit priorities from activity-based costing. Harvard Business Review, 130-135.

Cooper, R., \& Kaplan, R. S. (1991b). The design of cost management systems (1st ed.). Englewood Cliffs: Prentice Hall.

Cronbach, L. J. (1951). Coefficient alpha and the internal consistency of tests. Psychometrika, 16, $297-334$.

Cronbach, L. J. (1987). Statistical tests for moderator variables: flaws in analyses recently proposed. Psychological Bulletin, 102, 414-417.

Davenport, T. H. (2000). Mission critical. Realizing the promise of enterprise systems. Boston, MA: Harvard Business School Press.

Dechow, P. M., Richardson, S. A., \& Sloan, R. G. (2005). The persistence and pricing of the cash component of earnings. University of Michigan. Working paper. Dehning, B., \& Richardson, D. J. (2002). Returns of investments in information technology: a research synthesis. Journal of Information Systems, 16(1), 7-30.

Dewar, R., \& Werbel, J. (1979). Universalistic and contingency predictions of employee satisfaction and conflict. Administrative Science Quarterly, 24, $426-448$.

Dodd, D., \& Lavelle, W. (2002). ABC spells improved performance. High Volume Printing, 20(6), 20-29.

Doyle, S. (2002). Software review: is there a role for activity-based costing (ABC) in database marketing. Journal of Database Marketing, 10, 175-180.

Drake, A. R., \& Haka, S. F. (2008). Does ABC information exacerbate hold-up problems in buyer-supplier negotiations? The Accounting Review, 83(1), 29-60.

Drury, C. (2008). Management and cost accounting (7th ed.). London: Gengage Learning.

Dutz, M., \& Hayri, A. (1999). Does more intense competition lead to higher growth? CEPR. Discussion Paper No. 2249.

Edwards, J. B. (2001). ERP, balanced scorecard, and IT: how do they fit together? Journal of Corporate Accounting E' Finance, $12(5)$, 3-12.

Efendi, J., Mulig, E., \& Smith, L. (2006). Information technology and systems research published in major accounting academic and professional journals. Journal of Emerging Technologies in Accounting, 3, 117-128.

Estrin, T. L., Kantor, J., \& Albers, D. (1994). Is ABC suitable for your company? Management Accounting, 75, 40-45.

Galbraith, J. (1973). Designing complex organizations. Reading, MA: Addison-Wesley.

Gordon, L. A., \& Silvester, K. J. (1999). Stock market reactions to activity-based costing adoption. Journal of Accounting and Public Policy, 18(3), 229-235. 
Gosselin, M. (1997). The effect of strategy and organizational structure on the adoption and implementation of activity based costing. Accounting, Organizations and Society, 22(2), 105-122.

Govindarajan, V., \& Fisher, J. (1990). Strategy, control systems, and resource sharing: effects on business unit performance. Academy of Management Journal, 33(2), 259-285.

Granlund, M., \& Lukka, K. (1998). It's a small world of management accounting practices. Journal of Management Accounting Research, $10,153-179$.

Granlund, M., \& Malmi, T. (2002). Moderate impact of ERPS on management accounting: a lag or permanent outcome? Management Accounting Research, 13(3), 299-321.

Granlund, M., \& Mouritsen, J. (2003). Special section on management control and new information technologies. European Accounting Review, 12(1), $77-83$.

Gupta, A. K., \& Govindarajan, V. (1993). Coalignment between knowledge flow patterns and the strategic systems and processes within MNCs. In P. Lorange, B. Chakravarthy, J. Roos, \& A. Van de Ven (Eds.), Implementing strategic processes: Change, learning and cooperation (pp. 329-346). London: Basil Blackwell.

Hair, J. F., Jr., Anderson, R. E., Tatham, R. L., \& Black, W. C. (1998). Multivariate data analysis. New Jersey: Prentice-Hall.

Haldma, T., \& Laats, K. (2002). Contingencies influencing the management accounting practices of Estonian manufacturing companies. Management Accounting Research, 13(4), 379-400.

Hayes, R., \& Wheelwright, S. (1984). Restoring our competitive edge. New York: John Wiley \& Sons.

Hayes, D. C., Hunton, J. E., \& Reck, J. L. (2001). Market reaction to ERP implementation announcements. Journal of Information Systems, 15, 3-18.

He, Y. (2007). A research on the integration between ERP system and ABCM. In Proceedings of the 2nd international conference on research and practical issues of enterprise information systems (pp. 781-786). Beijing, China.

Hendricks, K. B., \& Singhal, V. R. (1997). Does implementing an effective TQM program actually improve operating performance? Empirical evidence from firms that have won quality awards. Management Science, 44, 1258-1274.

Henri, J. F. (2006). Management controls systems and strategy: a resource-based perspective. Accounting, Organizations and Society, 31, 529-558.

Hitt, L., Wu, D., \& Zhou, X. (2002). Investment in enterprise resource planning: business impact and productivity measures. Journal of Management Information Systems, 19(1), 71-98.

Holtzman, Y. (2004). The transformation of the accounting profession in the United States: from information processing to strategic business advising. Journal of Management Development, 23(10), 949-961.

Hope, J., \& Hope, T. (1997). Competing in the third wave: The ten management issues of the information age. Boston: Harvard Business School Press.

Hoque, Z. (2004). A contingency model of the association between strategy, environmental uncertainty and performance measurement: impact on organizational performance. International Business Review, 13(4), 485-502.

Hunton, J. (2002). Blending information and communication technology with accounting research. Accounting Horizons, 16(1), 55-67.

Hunton, J. E., Lippincott, B., \& Reck, J. L. (2003). Enterprise resource planning (ERP) systems: comparing firm performance of adopters and non-adopters. International Journal of Accounting Information Systems, 4(3), 165-184.

Hyvönen, J. (2007). Strategy, performance measurement techniques and information technology of the firm and their links to organizational performance. Management Accounting Research, 18(3), 343-366.

Innes, J., \& Mitchell, F. (1995). A survey of activity-based costing in the U.K.'s largest companies. Management Accounting Research, 6(2), 137-149.

Innes, J., Mitchell, F., \& Sinclair, D. (2000). Activity-based costing in the U.K.'s largest companies: a comparison of 1994 and 1999 survey results. Management Accounting Research, 11(3), 349-362.

Ittner, C. D., Lanen, W. N., \& Larcker, D. F. (2002). The association between activity-based costing and manufacturing performance. Journal of Accounting Research, 40(3), 711-726.

Jaccard, J., Turrisi, R., \& Wan, C. K. (1990). Interaction effects in multiple regression. Newbury Park: Sage.

Johnson, H. T. (1992). Relevance regained: From top-down control to bottom-up empowerment. New York: The Free Press.

Kaplan, R. (1993). Research opportunities in management accounting. Journal of Management Accounting Research, 5, 1-14.

Khanna, V. (2002). Learn the ABC of business. Businessline, 1.

Kinney, M. R., \& Wempe, W. F. (2002). Further evidence on the extent and origins of JIT's profitability effects. The Accounting Review, 77(1), $203-225$.

Kohli, R., \& Grover, V. (2008). Business value of IT: an essay on expanding research directions to keep up with the times. Journal of the Association for Information Systems, 9(1), 23-39.

Krumwiede, K. R. (1998). ABC: why it's tried and how it succeeds. Management Accounting, 79, 32-36.

Kudyba, S., \& Vitaliano, D. (2003). Information technology and corporate profitability: a focus on operating efficiency. Information Resources Management Journal, 16(1), 1-13.

La Porta, R., \& Lopenz-de-Silanes, F. (1999). The benefits of privatization: evidence from Mexico. Quarterly Journal of Economics, 114, $1193-1242$.

Lancaster, T. (1979). Econometric methods for the duration of unemployment. Econometrica, 47, 939-956.

Lea, B. R. (2007). Management accounting in ERP integrated MRP and TOC environments. Industrial Management \& Data Systems, 107(8), 1188-1211.

Lea, B. R., \& Min, H. (2003). Selection of management accounting systems in just-in-time and theory of constraints-based manufacturing. International Journal of Production Research, 41(13), 2879-2910.

Lee, Z., \& Lee, J. (2000). An ERP implementation case study from a knowledge transfer perspective. Journal of Information Technology, 15, 281-288.

Lowe, A. (2004). Postsocial relations: toward a performative view of accounting knowledge. Accounting, Auditing E Accountability Journal, 17(4), 604-628.

Maiga, A. S., \& Jacobs, F. A. (2008). Extent of ABC use and its consequences. Contemporary Accounting Research, 25(2), 533-566.

Malmi, T. (1997). Towards explaining activity-based costing failure: accounting and control in a decentralized organization. Management Accounting Research, 8(4), 459-470.

Melville, N., Kraemer, K., \& Gurbaxani, V. (2004). Review: information technology and organizational performance: an integrative model of IT business value. MIS Quarterly, 28(2), 283-322.

Milgrom, P. (1992). Economics, organization and management. Prentice-Hall.

Milgrom, P., \& Roberts, J. (1995). Complementarities and fit: strategy, structure, and organizational change in manufacturing. Journal of Accounting and Economics, 19, 179-208.

Miller, J. G., \& Vollman, T. E. (1985). The hidden factory. Harvard Business Review, 142-150.

Morrow, M., \& Connolly, T. (1994). Practical problems of implementing ABC. Accountancy, 5(3), 76-78.

Morton, N. A., \& Hu, Q. (2008). Implications of the fit between organizational structure and ERP: a structural contingency theory perspective. International Journal of Information Management, 28(5), 391-402.

Mukhopadhyay, T., Kekre, S., \& Kalathur, S. (1995). Business value of information technology: a study of electronic data interchange. MIS Quarterly, 19(2), $137-156$.

Newell, S., Huang, J., Galliers, R., \& Pan, S. (2003). Implementing enterprise resource planning and knowledge management systems in tandem: fostering efficiency and innovation incomplementarity. Information and Organization, 13(1), 25-52.

Nickell, S. (1996). Competition and corporate performance. Journal of Political Economy, 104, 724-746.

O'Connor, N. G., \& Martinsons, M. G. (2006). Management of information systems: insights from accounting research. Information E' Management, 43(8), $1014-1024$.

Otley, D. (1980). The contingency theory of management accounting: achievement and prognosis. Accounting, Organizations and Society, 5, 413-428.

Pattison, D., \& Arendt, C. (1994). Activity-based costing: it doesn't work all the time. Management Accounting, LXXV, 61-66.

Pizzini, M. J. (2006). The relation between cost-system design, managers' evaluations of the relevance and usefulness of cost data, and financial performance: an empirical study of US hospitals. Accounting, Organizations and Society, 31, 179-210.

Player, S., \& Cobble, C. (1999). Cornerstones of decision making: Profiles of enterprise ABM. Oakhill Press. 
Poston, R., \& Grabski, S. (2001). Financial impact of enterprise resource planning implementations. International Journal of Accounting Information Systems, 2(4), 271-294.

Quattrone, P., \& Hopper, T. (2005). A 'Time-space odyssey’: management control systems in multinational organizations. Accounting, Organizations and Society, 30(7-8), 735-764.

Rafiq, A., \& Garg, A. (2002). Activity based costing and financial institutions: old wine in new bottles or corporate panacea? Journal of Bank Cost and Management Accounting, 15(2), 12-28.

Rockart, J. F., Ear, M. J., \& Ross, J. W. (1996). Eight imperatives for the new IT organization. Sloan Management Review, $38(1)$, $43-56$.

Rom, A., \& Rohde, C. (2007). Management accounting and integrated information systems: a literature review. International Journal of Accounting Information Systems, 8, 40-68.

Sadagopan, S. (2003). Enterprise resource planning (pp. 169-184). Elsevier Science.

Sambamurthy, V., Bharadwaj, A., \& Grover, V. (2003). Shaping agility through digital options: reconceptualizing the role of information technology in contemporary firms. MIS Quarterly, 2(27), 237-263.

Scapens, R. W., \& Jazayeri, M. (2003). ERP systems and management accounting change: opportunities or impacts? A research note. European Accounting Review, 12(1), 201-233.

Schoonhoven, C. B. (1981). Problems with contingency theory: testing assumptions hidden within the language of contingency theory. Administrative Science Quarterly, 26, 349-377.

Shields, M. D. (1995). An empirical analysis of firms' implementation experiences with activity-based costing. Journal of Management Accounting Research, 7 , $148-166$.

Shrout, P. E., \& Fleiss, J. L. (1979). Intraclass correlations: uses in assessing reliability. Psychological Bulletin, 86, 420-428.

Sikora, R., \& Shaw, M. (1998). A multi-agent framework for the coordination and integration of information systems. Management Science, 44(11), 65-78.

Simoens, S., \& Scott, A. (2005). Integrated primary care organizations: to what extent is integration occurring and why. Health Services Management Research, 18(1), 25-40.

Skinner, W. (1974). The focused factory. Harvard Business Review, 52(3), 113-121.

Smith, K. W., \& Sasaki, M. S. (1979). Decreasing multicollinearity: a method for models with multiplicative functions. Sociological Methods and Research, 8, 35-56.

Southwood, T. R. E. (1978). Ecological methods. New York: Wiley.

Sutton, S. G. (2006). Extended-enterprise systems' impact on enterprise risk management. Journal of Enterprise Information Management, 19(1/2), 97-114.

Topkis, D. (1995). Comparative statics of the firm. Journal of Economic Theory, 67, 370-401.

Weiner, B. J., Savitz, L. A., Bernard, S., \& Pucci, L. G. (2004). How do integrated delivery systems adopt and implement clinical information systems? Health Care Management Review, 29(1), 1-16.

Wolak, R., Kalafatis, S., \& Harris, P. (1998). An investigation into four characteristics of services. Journal of Empirical Generalizations in Marketing Science, 3, $22-41$.

Wouters, M., \& Verdaasdonk, P. (2002). Supporting management decisions with ex ante accounting information. European Management Journal, 20(1), $82-94$. 